Stanisław R. ERDAWLETOW

Uniwersytet im. Al-Farabiego w Ałmaty

Danagul M. MUKATOWA

Kazachski Narodowy Uniwersytet Pedagogiczny im. Abaja w Ałmaty

\title{
ROZWÓJ BADAŃ NAUKOWYCH NAD TURYSTYKĄ W KAZACHSTANIE
}

\section{Turystyka jako dyscyplina naukowa ${ }^{1}$}

Współczesne zjawisko nazywane turystyką jest rozumiane na tyle szeroko i różnorodnie, że trudno określić, $\mathrm{w}$ jakim zakresie stanowi samodzielny fenomen, a w jakim ma ono do czynienia z innymi zjawiskami, np. psychologicznym, społecznym, gospodarczym, geograficznym, kulturowym (LISZEWSKI 2010). Turystykę należy uznać przede wszystkim za zjawisko przestrzenne i społeczno-gospodarcze, które w ogromnym stopniu wpływa na światową gospodarkę, na zachowanie ludzi, na środowisko przyrodnicze, życie kulturalne społeczeństw oraz na wiele innych sfer działalności człowieka.

Zjawisko turystyki ze względu na swoją złożoność i wieloaspektowość jest przedmiotem badań wielu dyscyplin naukowych zarówno teoretycznych, jak i stosowanych. Ale przy całej swej złożoności, jak już wcześniej nadmieniono, jest przede wszystkim zjawiskiem przestrzennym, społeczno-

1 Podział tekstu wraz z nadaniem tytułów wewnętrznych wprowadziła tłumaczka opracowania - Jolanta Wojciechowska. 
gospodarczym i kulturowym. Dlatego stał się przedmiotem zainteresowania co najmniej 30 dyscyplin naukowych odnoszących się do całego zakresu nauk humanistycznych, społecznych, przyrodniczych i technicznych. Wśród nich można wymienić: geografię, ekonomię, socjologię, psychologię, antropologię, kulturoznawstwo, historię, prawo, medycynę, fizjologię, balneologię, ekologię, urbanistykę, budownictwo i architekturę, etykę, estetykę, pedagogikę, zarządzanie, marketing, politologię, rolnictwo, czas wolny i rekreację, planowanie regionalne, transport, administrację, hotelarstwo i gastronomię oraz edukację. Listę tę można oczywiście wydłużyć.

W świecie nieustannie pojawia się wiele prac naukowych dotyczących turystyki - opisujących warunki jej funkcjonowania, aktualny stan i skutki rozwoju zarówno przyrodnicze, jak i społeczno-gospodarcze, a wszystko rozpatrywane w skalach: globalnej, krajowej, regionalnej i lokalnej. Autorzy tych prac reprezentują różne dyscypliny naukowe, a ich liczba wskazuje na szeroki zakres merytoryczny badań, w których obecnie narasta kwestia poszukiwania miejsca dla turystyki w systemie nauki. Świadczą o tym także konferencje i warsztaty odbywające się $\mathrm{w}$ różnych krajach świata, podczas których zagadnienie to było przedmiotem wielu sporów i emocjonujących dyskusji.

Problematyka poruszana w publikacjach i na konferencjach, zwłaszcza dotycząca metod badań naukowych oraz miejsca tych badań w systemie nauk, odzwierciedla rozbieżność poglądów na temat tego, czy można dziś mówić o turystyce jako samodzielnej nauce czy raczej mamy do czynienia $\mathrm{z}$ bardzo dynamicznym procesem powstawania nauk o turystyce lub nauk zajmujących się turystyką (WINIARSKI 2004).

W wielu krajach zwolenników „nauki o turystyce” jako niezależnej dyscypliny można znaleźć wśród przedstawicieli bardzo różnych dyscyplin naukowych. W niniejszym opracowaniu autorzy przeprowadzają analizę opartą na podstawie polskich badań (jako jednego z wiodących krajów w tym zakresie) oraz krajów WNP2.

W Rosji i innych krajach WNP, a także w Polsce istnieje znaczna liczba zwolenników jednej, samodzielnej nauki o turystyce. W Rosji jest ona różnie nazywana, np.: "tourizmologija” (Mironenko, Aleksandrowa), "turystyka” (Zorin, Kwartalnow) lub "turizmowiedenie" (Dolzhenko, Putrik, Okishiew, Kuskow). Na Ukrainie jest nazywana "turizmowiedenie" (Krachilo), a także

2 Wspólnota Niepodległych Państw - nazwa odnosi się do krajów po rozpadzie w 1991 r. Związku Socjalistycznych Republik Radzieckich (wyjaśnienie tłumaczki tekstu).

114 WARSZTATYZ GeOGRAFII TURYZMU 
"tourizmologija”, na Białorusi: „tourizmologija” (Pirozhnik) oraz "turystyka", zaś w Kazachstanie - "tourizmologija” (Erdawletow). Wymienione przykłady różnych określeń (których można by podać więcej) pokazują, że "tourizmologija" to współcześnie formułująca się nauka, i to głównie w szkołach wyższych krajów WNP. Na przykład w Rosji w szkolnictwie wyższym przedmiot „Turizmowiedenie” został wprowadzony w latach 90. ubiegłego wieku, a w Kazachstanie na potrzeby szkolenia kadr turystycznych w roku 2000 wprowadzono kurs o nazwie „Podstawy tourizmology”.

W publikacjach zgodnie podkreśla się, że „tourizmologija” jako dyscyplina naukowa jest wciąż nieugruntowana, a nieustrukturyzowane metody badawcze wymagają wyjaśnienia podstawowych pojęć oraz hipotez stawianych dla tego kierunku badań. $\mathrm{Z}$ drugiej strony $\mathrm{w}$ ostatnim czasie rosyjscy akademicy nawet definiują pojęcie "turizmowiedenie". Na przykład G. DOLZHENKO i Y. PUTRIK (2012) określają je jako: „gałąź wiedzy naukowej międzydyscyplinarnego charakteru obejmującą obszary aktywności różnych dyscyplin naukowych $\mathrm{w}$ badaniu zasobów turystycznych, technologii $\mathrm{i}$ jej wykorzystania w kreowaniu jak najlepszych warunków fizyczno-psychologicznych do życia człowieka, a także wpływu turystyki na środowisko przyrodnicze i społeczne oraz procesów zachodzących w sferze działalności turystycznej.". W innym artykule, ci sami autorzy wraz z A. Kuskov podają nieco inną definicję: „Turizmowiedenie to interdyscyplinarna dziedzina naukowa badająca warunki i procesy działalności turystycznej, w szczególności jej organizacyjne i gospodarcze aspekty oraz założenia prawne, wykorzystująca dla tych celów epistemologiczne fundamenty oraz metody badawcze nauk przyrodniczych, społecznych, humanistycznych i technicznych" (DOLZHENKO, PUTRIK, KUSKOW 2012).

Naszym zdaniem "tourizmologija" to kompleksowa, syntetycznie zintegrowana dyscyplina naukowa o turystyce, badająca jej organizacje przestrzennoczasową odpowiadającą za osiąganie przez ludność i gospodarkę kraju maksymalnych korzyści społeczno-ekonomicznych z działalności turystycznej. Obecnie mamy do czynienia z procesem formowania się tej nauki, a wkład w rozwój wnoszą dyscypliny naukowe zajmujące się jej badaniem fragmentarycznie, wyłącznie z punktu widzenia pola swoich zainteresowań. Proces odbędzie długą drogę, wiodącą od poglądów monodyscyplinarnych, mało skoordynowanych, do powstania systemowej wiedzy o turystyce.

Analizując możliwości powstania samodzielnej nauki o turystyce, warto sięgnąć także do racjonalnych powodów tego zamierzenia. Wśród nich najważniejszy jest brak możliwości przyznawania stopni naukowych $\mathrm{w}$ tej 
dziedzinie, czyli dziedzinie nieistniejącej nauki, nadal warunkowo nazywanej „nauką o turystyce”. Cierpią na tym głównie doktoranci na formalnie ustanowionych na uniwersytetach w wielu krajach kierunkach naukowych o nazwach: „turystyka”, „turystyka i rekreacja”, „rekreacja” itp. Ci ludzie są zmuszeni bronić się w ramach nauk podstawowych, takich jak: geografia, ekonomia, socjologia, historia, pedagogika (prawdopodobnie też innych).

W Polsce i krajach WNP powołanie w szkołach wyższych kierunków w zakresie wymienionych nazw (specjalności) nie opierało się na sformalizowanych naukowo (teoretycznie) zasadach. Realizacja tych uczelnianych kierunków, w praktyce stosowanych, wymaga uwzględnienia wielu innych dyscyplin naukowych, dla których turystyka jest fragmentem ich przedmiotu badań. To spowodowało konieczność stworzenia nie tylko interdyscyplinarnego programu nauczania, ale także systemu nauk turystycznych. Program ten wziął niejako na siebie odpowiedzialność w dążeniu ku zbudowaniu ogólnej teorii turystyki, stanowiąc podstawę naukowego szkolenia studentów na uniwersytetach oraz prowadzenia interdyscyplinarnych badan nad turystyką.

Ogólna teoria turystyki, pomimo złożoności i wielowymiarowości zjawiska, na uniwersytetach jest rozpatrywana w kontekście działalności gospodarczej oraz metod formowania osobowości poprzez sposoby poznawania świata, regeneracji sił fizycznych i psychicznych, a także rozwój twórczych możliwości człowieka. Ogólnie mówiąc, wyjaśnia ona podstawowe pojęcia i koncepcje związane $z$ turystyką, prezentuje aktualny stan jej rozwoju, zróżnicowanie przestrzenne, jak również efekty oraz wpływ na środowiska: naturalne, społeczne, gospodarcze, kulturalne i inne. Te programy akademickie charakteryzuje jedno - dążenie do syntezy w charakterystyce zjawisk turystycznych. A to naszym zdaniem wyjaśnia potrzebę stworzenia jednolitej „nauki o turystyce”, obecnie różnorodnie nazywanej: „tourizmologija”, , turizmowiedenie”, ,turizmografija”, ,turografija”, „turystyka”, ,turologija”, "turistologija”, ,turopedija”, ,turistskaja technologija”, ,podstawy turystyki" itp.

Pomysł interdyscyplinarnych badań nad turystyką, a w konsekwencji uznanie dyscyplin naukowych składających się (w różnym stopniu) na naukę o turystyce, nie jest niczym nowym. Argumenty zwolenników nauk o turystyce pokazują, że szanse skutecznych badań turystyki zarówno w zakresie teorii, jak i praktyki zapewniają interdyscyplinarne nauki. Innymi słowy można powiedzieć, że konieczne jest uznanie faktu, jakim jest powstawanie

116 WARSZTATY Z GEOGRAFII TURYZMU 
systemu nowoczesnych nauk, który można nazwać naukami o turystyce. Elementem łączącym nauki o turystyce powinna być zdolność rozwiązywania problemów teoretycznych, wyrażająca się w tworzeniu częściowej lub ogólnej teorii turystyki, z jednoczesnym formułowaniem i rozwiązywaniem ważnych problemów badawczych służących zarówno rozwojowi nauk o turystyce, jak i potrzebom praktycznego rozwoju turystyki we współczesnym świecie.

Podczas odbywającej się dyskusji na temat obecnego stanu oraz rozwoju przyszłych kierunków badań naukowych nad turystyką często podkreśla się, że istotny wpływ będą miały koncepcje wyrastające $\mathrm{z}$ nowych trendów w filozofii zarządzania nauką. Zwolennicy tej tezy prawdopodobnie opierają się na głębi filozofii nauki, dającej możliwość poznania ogólnych praw natury i społeczeństwa oraz myślenia w kontekście ogólnej metodologii.

Zgodnie z ogólną znajomością wiedzy wydaje nam się, że geografia czy raczej nauki geograficzne stanowią podstawę dla systemu nauk o turystyce i są najbardziej do tego odpowiednie. Po pierwsze dlatego, że geografia jest tak obszerna jak filozofia w poznawaniu otaczającego nas świata i jej największym wyzwaniem jest kompleksowe badanie przyrody, społeczeństwa oraz gospodarki, łącznie z określaniem charakteru wzajemnych interakcji między społeczeństwem a środowiskiem geograficznym (otoczeniem). Po drugie - turystyka jest niczym innym jak "geograficzną wiedzą o Ziemi", zatem turystyka i geografia są ze sobą nierozerwalnie związane, ponieważ geografia jest nauką, zajmującą się całością zjawisk oraz procesów przyrodniczych i społecznych $w$ ich przestrzennym wymiarze (ERDAWLETOW 2000).

Zaproponowaną tezę potwierdza również fakt wzrastającej roli geografii turyzmu - jako nauki - w badaniach nad turystyką w krajach WNP. Ta zintegrowana syntetycznie nauka bada przestrzenną (terytorialną) organizację turystyki. Przedmiotem jej analiz i syntez są formy oraz relacje przestrzenne zjawisk turystycznych i związanych z nimi procesów, które zmieniają i przekształcają przestrzeń. W przeciwieństwie do innych nauk, geografia turyzmu rozpatruje turystykę jako zintegrowany system społeczno-gospodarczy, badając praktycznie wszystkie aspekty działalności turystycznej: naturalne, geograficzne, społeczno-ekonomiczne, ekologiczne, polityczne, historyczne, technologiczne $\mathrm{i}$ inne. 


\section{Skala i struktura badań nad turystyką w Kazachstanie w ujęciu chronologicznym}

Do 1991 roku Kazachstan był republiką stanowiącą część ZSRR³. Wtedy cały rozwój turystyki, w tym wsparcie badań naukowych było centralnie sterowane poprzez główny ośrodek Związku Radzieckiego, czyli Moskwę. Jeśli nie weźmie się pod uwagę prac podejmowanych w Państwowym Instytucie Projektowym (GPI) „Kazgiprograd”4, gdzie zdobywano doświadczenia $\mathrm{w}$ projektowaniu rozwoju rekreacji i turystyki tylko dla niektórych regionów kraju, można powiedzieć, że $w$ radzieckim Kazachstanie właściwie nie prowadzano badań naukowych w zakresie turystyki.

Wraz z upadkiem ZSRR suwerennemu Kazachstanowi przyszło samodzielnie decydować o licznych problemach, którymi wcześniej się nie zajmował. W szczególności odnosi się to do złożonych zagadnień dotyczących rozwoju turystyki. Pomimo już ponad 20-letniej niezależności politycznej Kazachstanu, kraj ten wciąż nie rozwinął nowoczesnego przemysłu turystycznego, w wyniku czego turystyka znajduje się na niskim poziomie rozwoju (jej udział w PKB kraju wynosi mniej niż jeden procent). W Kazachstanie de facto istnieje turystyka, ale nie de iure, pomimo funkcjonowania od 1991 roku (w różnych postaciach) Krajowej Administracji Turystyki. Kraj stoi obecnie przed zadaniem budowy nowoczesnego, wysokoefektywnego przemysłu turystycznego, jednak wiele problemów realizację tego wyzwania uniemożliwia. Zwłaszcza brakuje wsparcia naukowego $\mathrm{w}$ procesach rozwijania turystyki i jej organizacji $\mathrm{w}$ przestrzeni. O tym, że prawidłowy rozwój turystyki nie może obyć się bez pomocy nauki, nie trzeba nikogo przekonywać. Niemiecki matematyk Carl Gauss kiedyś powiedział: „Nie ma nic bardziej praktycznego, niż dobra teoria".

Rozwój badań naukowych w turystyce jest ponadto hamowany przez trudności, jakie występują $\mathrm{w}$ uzyskaniu stopni i tytułów naukowych $\mathrm{w}$ tej dziedzinie. Odnosi się to zwłaszcza do młodych naukowców, którzy często muszą dostosować tematy swoich dysertacji do wąskich problematyk badawczych ośrodków posiadających uprawnienia do nadawania stopni naukowych.

${ }^{3}$ ZSRR - Związek Socjalistycznych Republik Radzieckich, również stosowano skrót Związek Radziecki (wyjaśnienie tłumaczki tekstu).

${ }^{4}$ Gosudarstwiennyj Projektnyj Institut (GPI). 
Badania naukowe w dziedzinie geografii wypoczynku i turystyki w Kazachstanie zaczęły nabierać kształtu w latach 70. XX wieku. Pierwszy w prowadzeniu prac naukowo-badawczych i projektowych był wspomniany wcześniej Państwowy Instytut Projektowy (GPI) „Kazgiprograd”, w którym pracował w tym czasie zespół składający się z wykwalifikowanych architektów, geografów, ekonomistów, inżynierów oraz przedstawicieli innych zawodów. W GPI „Kazgiprograd” w trakcie ponad 20-letniego okresu opracowano dla ówczesnej republiki liczne programy rozwoju gospodarki turystycznej. Można tu wymienić: „Program rozwoju stref wypoczynkowych (baz) w Kazachskiej SRR w latach 1976-1990” (1977) lub „Program rozwoju i lokalizacji baz turystycznych na terytorium Kazachskiej SRR do roku 2000" (1983). Prace te należy zaliczyć do najbardziej znaczących wśród innych opracowań dotyczących zagadnień architektoniczno-projektowych w organizowaniu miejsc wypoczynkowych i turystycznych w Kazachstanie. Stwierdzono w nich, że zagospodarowanie atrakcyjnych turystycznie obszarów kraju powinno być prowadzone konsekwentnie, z uwzględnieniem przyrodniczego i historyczno-kulturowego potencjału terytorium, z możliwością organizowania szlaków turystycznych, transportu i komunikacji, przy zastosowaniu nowoczesnego wyposażenia, wsparcia technicznego oraz zatrudnienia ludności. Każda $\mathrm{z}$ wówczas wydzielonych stref krajobrazowo-rekreacyjnych była oceniana pod kątem przydatności dla różnych rodzajów aktywności rekreacyjnej. Zastosowany system oceny warunków naturalnych i innych zasobów pozwalał porównywać ze sobą różne obszary i określać możliwości rozwoju masowych form turystyki na terenie republiki. W granicach Kazachstanu wydzielono wówczas około 60 stref turystycznych i rekreacyjnych występujących w 16 regionach kraju.

Należy zaznaczyć, że GPI „Kazgiprograd” w latach 1970-1980 był głównym wykonawcą projektów dotyczących zagadnień turystycznych w Kazachstanie. Pod koniec 1980 roku zaczęły się pojawiać opracowania naukowoprojektowe także innych instytucji, jednak były one prowadzone głównie na szczeblu regionalnym. Na przykład grupa naukowców z Wydziału Geografii na Narodowym Uniwersytecie KazNu Al-Farabi w Ałmaty, razem z pracownikami oddziału architektury w obwodzie dżambylskim przeprowadziła badania na temat „Koncepcja rozwoju i rozmieszczenia przemysłu turystycznego w obwodzie dżambylskim w latach 1990-2005" (ERDAWLETOW, rękopis). Badania obejmowały analizę stanu rozwoju turystyki oraz koncepcję rozwoju i lokalizacji w przyszłości przedsiębiorstw turystycznych na terenie obwodu oraz opracowanie dla niego mapy turystycznej. Efektem 
tej pracy było wydanie w 1990 roku w Mińsku turystycznej mapy obwodu dżambylskiego, w skali 1 : 750 000. Zostały ponadto zainicjowane prace nad Turystycznym atlasem miasta Dżambyl o kieszonkowym formacie. Byłby to trzeci w ZSRR tego rodzaju atlas, po Moskwie i Mińsku, ale niestety w połowie prace przerwano, ze względu na początki „gorbaczowskiej pierestrojki".

Rozpad Związku Radzieckiego przyczynił się do uzyskania suwerenności Kazachstanu, ale również do głębokiego kryzysu gospodarczego z powodu upadku narodowego kompleksu gospodarczego kraju. Wystąpił także zastój w pracach naukowo-badawczych i projektowych. Jego konsekwencją było zamknięcie kolosa GPI „Kazgiprograd”, który został podzielony na odrębne małe biura.

We wczesnych latach 90. XX wieku szczególną aktywność w pracach projektowych dotyczących turystyki wykazała grupa kierowana przez E. Muchamietszina, która opracowała dwa bardzo ważne projekty. Pierwszy pt. „Kompleksowe studium badań w zakresie rozmieszczenia obiektów turystycznych wzdłuż kazachskiego odcinka Jedwabnego Szlaku. Podstawy koncepcji” (1991) i drugi zatytułowany „Projekt narodowego programu rozwoju przemysłu turystycznego w Republice Kazachstanu” (1993), który odegrał ważną rolę w przyszłej koncepcji rozwoju turystyki w kraju, opartej na wykorzystaniu przyrodniczych i społeczno-ekonomicznych zasobów turystyczno-rekreacyjnych.

Niektórzy badacze zaczęli pracować na zasadach prywatnej przedsiębiorczości, realizując zlecenia zainteresowanych instytucji lub organizacji. Z powstałych wówczas prac warto wymienić Mapę obrvodu Atmaty dla myśliwych i rybakóww w skali 1 : 800000 (CZIKOWANI 1993). Do ciekawych opracowań należy mapa pt. Mapa zasobów turystyczno-rekreacyjnych Semirecza (Siedmiorzecza) (NAZARCZUK, GIROWKA 1997), przygotowana w oparciu o krajobrazy i z uwzględnieniem jakościowej oceny turystyczno-rekreacyjnych zasobów regionu. W 1998 roku ukazała się mapa pt. Przyrodnicze rezerwaty Republiki Kazachstanu w skali 1 : 3500000 (NAZARCZUK, BAIZAKOW, DUDUKALOWA i in. 1998), która prezentuje zarówno istniejące, jak i potencjalne rezerwaty, a także inne zasoby przydatne do rozwijania w kraju różnych form turystyki masowej. Została również opublikowana oryginalna mapa pt. Obiekty turystyki ekologicznej w okolicach Atmaty w skali 1: 60000 (FISHMAN, FIRSOWA 1999), mimo pewnych nieścisłości była przedmiotem zainteresowania nie tylko wśród turystów, ale także nauczycieli i studentów szkół wyższych przygotowujących specjalistów do pracy w turystyce.

120 WARSZTATY Z GeOGRAFII TURYZMU 
Pod koniec lat 90. minionego wieku uaktywnił się $\mathrm{w}$ badaniach naukowych w dziedzinie wypoczynku i turystyki Instytut Geografii Państwowej Akademii Nauk. Grupa pracowników tego Instytutu, skupiona w laboratorium geoekologicznych problemów obszarów górskich, przeprowadziła pod kierunkiem W. Popova w latach 1997-1999 kompleksowe badania w zakresie rekreacyjnych zasobów Północnego Tien Szanu. Analizowano czynniki i warunki sprzyjające uprawianiu różnych typów aktywności rekreacyjnej w każdej górskiej miejscowości, a ponadto opracowano metody kartograficznej prezentacji górskich terenów rekreacyjnych. $W$ rezultacie tych badań przygotowano i opisano zasady oceniania zasobów rekreacyjnych na obszarach górskich. Metody te mogą być wykorzystywane także w innych górskich regionach Kazachstanu oraz w sąsiednich krajach.

W 1996 roku na Wydziale Geograficznym Narodowego Uniwersytetu KazNu Al-Farabi w Ałmaty powołano samodzielną Katedrę Turystyki, co przyczyniło się do wyraźnego postępu badań naukowych w Kazachstanie $\mathrm{w}$ dziedzinie rozwoju turystyki i jej terytorialnej organizacji. Ponadto badania te zaczęły koncentrować się $\mathrm{w}$ tej wiodącej w kraju uczelni. W 2000 roku Katedra wygrała grant w zakresie badań podstawowych w konkursie ogłoszonym przez Ministerstwo Edukacji i Nauki Republiki Kazachstanu na temat: "Ocena zasobów rekreacyjnych jako podstawa do zrównoważonego rozwoju przemysłu turystycznego Kazachstanu". Obecnie Katedra Turystyki Narodowego Uniwersytetu KazNu Al-Farabi stała się największym ośrodkiem badań naukowych w dziedzinie turystyki w Kazachstanie. To właśnie tutaj, na Wydziale Geografii w 1998 roku powstała pierwsza w Kazachstanie Rada ds. Dysertacji Doktorskich w specjalności "geografia ekonomiczna, społeczna i polityczna", której częścią jest geografia turyzmu - nowa dyscyplina naukowa w Kazachstanie i WNP.

Przewodniczącym tej Rady i jednocześnie jej inicjatorem został prof. S.R. Erdawletow - autor pierwszych w Kazachstanie teoretycznych opracowań oraz podręczników akademickich z zakresu geografii turystyki. Autor ten dał podwaliny dla geografii turystyki w Kazachstanie. Dziś można powiedzieć, że pod jego kierownictwem powstała kazachska naukowa szkoła geografii turyzmu. Szkoła ta uprawia naukę przyszłości, której celem jest przede wszystkim rozwiązywanie problemów w dziedzinie rozwoju turystyki i jej terytorialnej organizacji $\mathrm{w}$ kraju, przy wydatnym wsparciu naukowym. W czasie funkcjonowania Rady ds. Dysertacji Doktorskich obroniło się w dziedzinie geografii turystyki 10 jego doktorantów. 
Pewien wkład w rozwój nauki o turystyce przynoszą także inne uczelnie w kraju. Spośród nich należy wymienić: Katedrę Turystyki na Uniwersytecie Turan (W.N. Wukolov, W.A. Korabliew i in.), Wydział Turystyki na Kazachskiej Akademii Sportu i Turystyki (A.N. Makagonov, M.K. Nazarchuk i in.), a także katedry prowadzące szkolenia kadr dla turystyki w KazNPU im. Abaja, w Południowo-Kazachstańskim Uniwersytecie im. Auezova, w Eurazjatyckim Uniwersytecie im. L. Gumilewa (O.B. Mazbaew, A.A. Saipow i in.), w Kazachskim Uniwersytecie Ekonomicznym i innych. Każda z wymienionych uczelni wnosi swój wkład w formowanie "tourismology" w Kazachstanie.

Należy zaznaczyć, że obecnie w Kazachstanie realizacja badań naukowych w dziedzinie turystyki w dużej mierze związana jest $\mathrm{z}$ doskonaleniem kształcenia dla niej kadr. To odnosi się nie tylko do badań prowadzonych w szkołach wyższych, ale także do nielicznych instytucji badawczych. Przygotowywaniu kadr dla turystyki wymaga wiedzy uzyskiwanej na polu nauk geograficznych. Chodzi tu o różne opracowania badawcze, ale także o publikowanie przewodników turystycznych czy map powstałych na podstawie nowoczesnych technologii geoinformacyjnych itp. (WUKOLOW 2013). W rozwiązywanie tych problemów aktywnie zaangażowany jest Instytut Geografii Ministerstwa Edukacji i Nauki Republiki Kazachstanu. Jego pracownicy przeprowadzili w latach 2012-2014 fundamentalne badania nt. „Geograficzne wsparcie przyspieszonego rozwoju turystyki w Kazachstanie". Zatem badania geograficzne przyczyniają się do planowania i prognozowania turystyki jako ważnego segmentu gospodarki, a także do tworzenia własnej, krajowej szkoły turystyki. Z udziałem geografów nauczycieli akademickich dokonuje się rozwój takich kierunków badawczych i edukacyjnych, jak: geografia turystyki, pedagogika turystyki i podstawy prawne turystyki (MIEDIEU, PLOHIH 2010).

Problematyka turystyki jest ponadto wprowadzana w ramach poszczególnych projektów krajowych. Tak więc zgodnie z programem narodowego projektu zatytułowanego „Dziedzictwo kulturowe Kazachstanu” realizowane są takie tematy, jak: "Zabytki piśmiennictwa i archeologia Południowego Kazachstanu”, ,Kazachstan w średniowieczu (VI-XV w.)", "Życie duchowe Kazachów w XIX-XX w.”, „,Badania archeologiczne starożytnego miasta Żarkent”, ,Zbiory etnograficzne Centralnego Państwowego Muzeum Republiki Kazachstanu”, ,Kompleksowe badania dziedzictwa narodowego wraz z dużymi centrami naukowymi”; "Muzealnictwo Kazachstanu”, ,Ekspedycyjno-etnograficzne badania miejsc historycznych" (Kulturnoje nasliedije 2004). 
Przy znaczącej popularności turystyki w Kazachstanie dziwi fakt, że nie występuje ona w wykazie dyscyplin naukowych państwowej komisji (WAK). Jeśli naprawdę w Kazachstanie ma powstać nowoczesny i wysokoefektywny przemysł turystyczny, to nie może się to odbyć bez możliwości prowadzenia w tym zakresie naukowych badań. W związku z tym konieczne jest włączenie do spisu „Nomenklatury naukowych specjalności” przez państwową komisję (WAK) co najmniej trzech nowych specjalności: "geografia turystyki”, „ekonomika i organizacja turystyki” oraz "pedagogika i psychologia turystyki". Powinny one być zapisane w odpowiednich sekcjach określonych nauk: geograficznych, ekonomicznych i pedagogiczno-psychologicznych. Ułatwiłoby to prowadzenie badań naukowych w zakresie złożonych zagadnień i problemów społeczno-gospodarczych oraz przestrzennych odnoszących się do rozwoju turystyki i jej terytorialnej organizacji. Tym bardziej jest to istotne, że potrzeba ta została oficjalnie zapisana w 2001 roku w przyjętym dokumencie pt. „Koncepcja rozwoju turystyki w Republice Kazachstanu". Ponadto taka potrzeba jest motywowana również tym, że od 2011 roku w kraju odbywają się kolokwia na stopień doktora habilitowanego.

W nowej wersji dokumentu pt. „Koncepcja rozwoju przemysłu turystycznego w Republice Kazachstanu" ani w celach, ani zadaniach rozwoju turystyki do 2020 roku nie uwzględniono kwestii badań naukowych w zakresie turystyki. Narodowa administracja turystyki powinna znaleźć możliwości organizacyjne i finansowe, aby utworzyć państwowy naukowo-badawczy Instytut Turystyki, który wziąłby na siebie odpowiedzialność wsparcia naukowego w kwestii rozwoju turystyki i jej terytorialnego systemu organizacji w Republice Kazachstanu. Kraj posiada podstawowy kapitał ludzki do tego, aby mogła powstać taka instytucja, a jej istnienie pomogłoby przejść od obecnie rozproszonych i amatorskich działań podejmowanych w zakresie turystyki do rozwiązywania problemów kompleksowo, w sposób odpowiedzialny i oparty na nauce.

Warto dodać jeszcze jeden fakt. Na Narodowym Uniwersytecie KazNu Al-Farabi w Ałmaty przy Katedrze Geografii Rekreacji i Turystyki został otwarty przewód doktorski (PhD) w specjalności „turystyka” (2010), a na Wydziale Geografii i Ochrony Środowiska były przeprowadzone dysertacje absolwentów studiów doktoranckich (2013), natomiast na doktoraty w tej specjalności nie były i w dalszym ciągu nie są przydzielane państwowe granty. Urzędnik Ministerstwa Edukacji i Nauki przydziela granty doktorantom funkcjonującym w katedrach geografii lub ekonomii, uważając, że nie 
ma takiej nauki, jak turystyka. Logikę w tych działaniach trudno dostrzec, gdyż to urzędnicy powinni wiedzieć, że na uniwersytetach jest nauka, której ogólna nazwa brzmi „podstawy tourismology”. Konsekwencją przydzielania grantów doktoranckich w specjalności „turystyka” powinno być to, że absolwenci ostatecznie powinni uzyskiwać stopień naukowy „doktor tourismology” lub „doktor o specjalności: turystyka”. Nie warto, aby Kazachstan, który w WNP jest liderem w wielu dziedzinach, miał problemy i kompleksy, bo nie uznaje się turystyki jako nauki.

\section{Zakończenie}

Współczesna turystyka dzięki swojej złożoności, wszechstronności i różnorodności jest przedmiotem zainteresowania wielu teoretycznych oraz stosowanych dyscyplin naukowych. W świecie ciągle powstaje wiele prac naukowych zajmujących się turystyką w skali globalnej, krajowej, regionalnej i lokalnej. W tych pracach, a także na licznych konferencjach naukowych i sympozjach trwa dyskusja na temat tego, czy można mówić o samodzielnej nauce o turystyce, czy raczej o zbiorze nauk o turystyce. Pomimo tej debaty, wiele uniwersytetów w Europie i WNP, poprzez opracowanie na bazie interdyscyplinarności specjalistycznych programów nauczania z turystyki i rekreacji, wzięło na siebie odpowiedzialność za stworzenie ogólnej teorii turystyki, która jest podstawą w szkoleniu studentów oraz stanowi próbę syntetycznego ujęcia zjawisk turystycznych.

W ostatnich latach w krajach WNP wzrasta rola geografii, której reprezentanci postrzegają turystykę jako zintegrowany system społeczno-ekonomiczny i badaniom poddają wszystkie aspekty działalności turystycznej: fizycznogeograficzne, społeczno-ekonomiczne, ekologiczne, polityczne, historyczne $\mathrm{i}$ inne.

Turystyka jako nauka pojawiła się także w suwerennym Kazachstanie. Do dzisiaj jednak w kontekście sektora gospodarki nie ma ustalonych ram co do naukowego wsparcia jej rozwoju. Badania naukowe w zakresie turystyki prowadzą wiodące w kraju uczelnie, które kształcą również kadry turystyczne, oraz Instytut Geografii w Ministerstwie Edukacji i Nauki. 


\section{Bibliografia}

ВукОЛОв В.Н. 2013, Информационно-аналитический обзор современного состояния исследования сореры туризма в СНГ и РК, [w:] Тендениии, проблемы, перспективы индустриально-инноваиционного и устойчивого развития туризма, Астана, s. 9-17.

ДОЛЖЕНКО Г.П., ПуТРИК Ю.С., 2012, Туризмоведение - формируюшаяся научная дисииплина о сфере туризма, „Вопросы туризмоведения”, № 2(2), s. 5-11.

ДОЛЖЕНКО Г.П., ПУТРИК Ю.С., КУСКОВ А.С., 2012, Российское туризмоведение (хронология выдающихся событий, изданий научной митературы, докторских диссертаций), [w:] Возможности развития туризма Сибирского региона и сопредельных территорий, Томск, s. 82-88.

ЕРДАВЛЕТОВ С.Р., 2000, География туризма: история, теория, методы, практика, Атамұра, Алматы:. Культурное наследие. Национальный проект, 2004, www.madenimra.kz.

МЕДЕУ А., ПЛОхИХ Р., 2010, Проблема профессионального туристского образования в Казахстане, Центр Азия www.centralasia.ru.

CZIKOWANI L., 1993, Mapa obwodu Atmaty dla myśliwych i rybaków w skali 1 : 800 000, Mińsk.

FISHMAN J., FIRSOWA O., 1999, Mapa. Obiekty turystyki ekologicznej w okolicach Atmaty w skali 1 : 60000.

LISZEWSKI S., 2010, Nauka czy nauki o turystyce, "Turyzm”, 20, 2, s. 37-45.

NAZARCZUK M., GIROWKA N., 1997, Mapa zasobów turystyczno-rekreacyjnych Semirecza, w skali $1: 100000$.

NAZARCZUK M., BAIZAKOW T., DudukAlOWA S. i in., 1998, Mapa. Przyrodnicze rezerwaty Republiki Kazachstanu w skali $1: 3500000$.

WINIARSKI R. (red.), 2004, Nauki o turystyce, „Studia i Monografie”, 7 (część 1 i 2), AWF, Kraków. 